\title{
Calculation of the Index of Turkey's Vulnerability in Natural Disasters
}

\author{
Sedat Bostan', Ünal Yaprak ${ }^{2}$ \\ 'Health Management Department, Gümüşhane University School of Health Sciences, Gümüşhane, Turkey \\ 2Disaster Management PhD Student, Gümüşhane University School of Health Sciences, Gümüşhane, Turkey
}

Cite this article as: Bostan S, Yaprak Ü. Calculation of the Index of Turkey's Vulnerability in Natural Disasters. Eurasian J Emerg Med 2017; 16: 102-11

\begin{abstract}
Aim: The aim of this study was to determine the vulnerability levels of Turkey in terms of natural disasters and to guide decision makers and strategists in this field. In the study, disaster data obtained for 1987-2011 were used, and the disaster of type was most observed in our country.

Materials and Methods: Data vulnerability indices against the disasters were calculated using a Data Envelopment Analysis Program (DEAP) 2.1 program with a Data envelopment analysis-based output-oriented Malmquist Total Factor Productivity Index method.

Results: The regions of Turkey, which have the highest vulnerability index for the disasters, were TRA2 (0.323), TRB2 (0.305), and TRB1 (0.287) regions. In addition, it was seen that in the Black Sea region, the TR82 (0.267) region was more vulnerable than the other places of the region. In this study, a picture of the whole country over a period of 25 years in terms of disasters was captured.

Conclusion: In the picture, it is seen that economic and social costs endured due to disasters are separated into two regions starting from the region of Eastern Anatolia and the north branch extends across the Black Sea region and the other south branch reaches to the Mediterranean.
\end{abstract}

Keywords: Disaster, vulnerability, Turkey, data envelopment analysis

\section{Introduction}

Millions of people are affected by the disasters arising annually due to natural and man-made situations in our country and in the world. Many losses of lives and injuries are seen and thus an economic loss of billions of dollars arises. In addition, the disasters affect infrastructures and superstructures of countries and interrupt the transportation, communication, and education and health services at different levels (1). According to the publication prepared by the Department of Disaster Investigation and Damage Assessment affiliated to Ministry of Public Works and Settlement, General Directorate of Disaster Affairs from 1950 to 2008, percentages of the numbers of affected people based on disaster types in our country were as follows: $55 \%$ for earthquake; $21 \%$ for landslide; $8 \%$ for flood and in- undation; $7 \%$ for rock fall; $2 \%$ for avalanche; $4 \%$ for more than one disaster type (such as both landslide and inundation); and 3\% fire, geo-medical problems, cave collapses, storm, twister, etc.

The percentage distribution of the disasters in our country is as follows: $45 \%$ for landslide, $18 \%$ for earthquake, $14 \%$ for flood inundation, $10 \%$ rock fall, $2 \%$ for avalanche, $7 \%$ for multiple disasters, and $4 \%$ for other disasters. In addition, $43.75 \%$ of accommodation units (province, town centers, town, city, and villages) of our country have been exposed to at least one disaster type.

In contrast, Erzurum, Bingöl, Trabzon, Rize, Tunceli, Kastamonu, Erzincan, Malatya, Artvin, and Sivas rank first in terms of disaster number, whereas Kocaeli, Bingöl, Erzurum, Sakarya, Van, Düzce, Yalova, Adana, Muş, and Diyarbakır occupy the top in terms of disaster victim number (2).

\section{Correspondence to: Sedat Bostan e-mail: sbostan29@gmail.com}


In addition, when the archived records of T.R. Red Crescent Society and disaster data of Turkey Disaster Data Bank (TDDB) obtained for 1980-2012 were reviewed, an earthquake was noted every 7 months on an average, flood every 2 months, landslide every 4 months, and fire disaster every 4 months in our country according to disaster criteria of Emergency Events Database (EMDAT) and Centre for Research on the Epidemiology of Disasters (CRED; observing at least one of the following conditions: at least $\geq 10$ deaths, existence of 100 or more affected people, and exception reporting or international call for aid). Moreover, according to the studies, the disaster numbers in our country tended to increase, whereas this increase was more apparent after 2000 (3).

Disasters cause the gross domestic product (GDP), consumption, and fortune to decrease by economically reducing the capital stock and production efficiency of capital in a global and national sense (4). For example in Belize, a country in Central America, the loss that arose from two hurricanes occurred in 2000 and 2001 corresponded to 33\% (280 million dollars) and 30\% (250 million dollars) of GDP, respectively. Thus, the financial status of the country worsened, and a reconstruction operation was needed for public debt in 2006 (5). According to a study that investigated the effects of disruptive disasters occurring in 196 countries between 1970 and 2008 on GDP, these disasters led to about $2.3 \%$ decrease on the output both in the short and long term (6).

In our country, total economic loss arising from Kocaeli and Düzce earthquakes in 1999, and Van earthquake in 2011 was 22.5 million dollars. The Marmara earthquakes in 1999 resulted in an estimated decrease in GDP to $6.1 \%$ (7).
From a global perspective, according to "Global Disaster Hotspots" conducted using EMDAT database, i.e., according to the determination of risky regions worldwide in terms of disasters, the Anatolia geography in Turkey is among the most risky regions for losses arising from earthquake, flood, drought, and storm disasters (Figure 1).

It is not possible to completely eliminate the disasters. Therefore, it is important that some risks are determined to be prepared for disasters, and accordingly, some measures are taken. Therefore, $48 \%$ of a source of 4.4 billion dollars, which was created by International Federation of Red Cross and Red Crescent Societies (IFRC), World Vision International, International Committee of the Red Cross, and World Food Programme are used for charities, whereas $52 \%$ thereof are used for predisaster precaution and charity programs (8).

Heavy losses that arose from the Marmara earthquake in 1999 in our country revealed our deficiencies about education, preparedness, planning, and damage reduction related to disasters and disaster management (9). After these disasters, an intervention-based crisis management has been transformed to a preparedness-based risk management in the disaster management in our country.

Risk is defined as potential losses that may be incurred based on the damage the elements under danger in the region will endure in the case that any danger is occurred in a particular location at a given time.

Vulnerability is defined as a degree of possible loss of life, injury, damage, destruction, loss, and harm, which may be en-

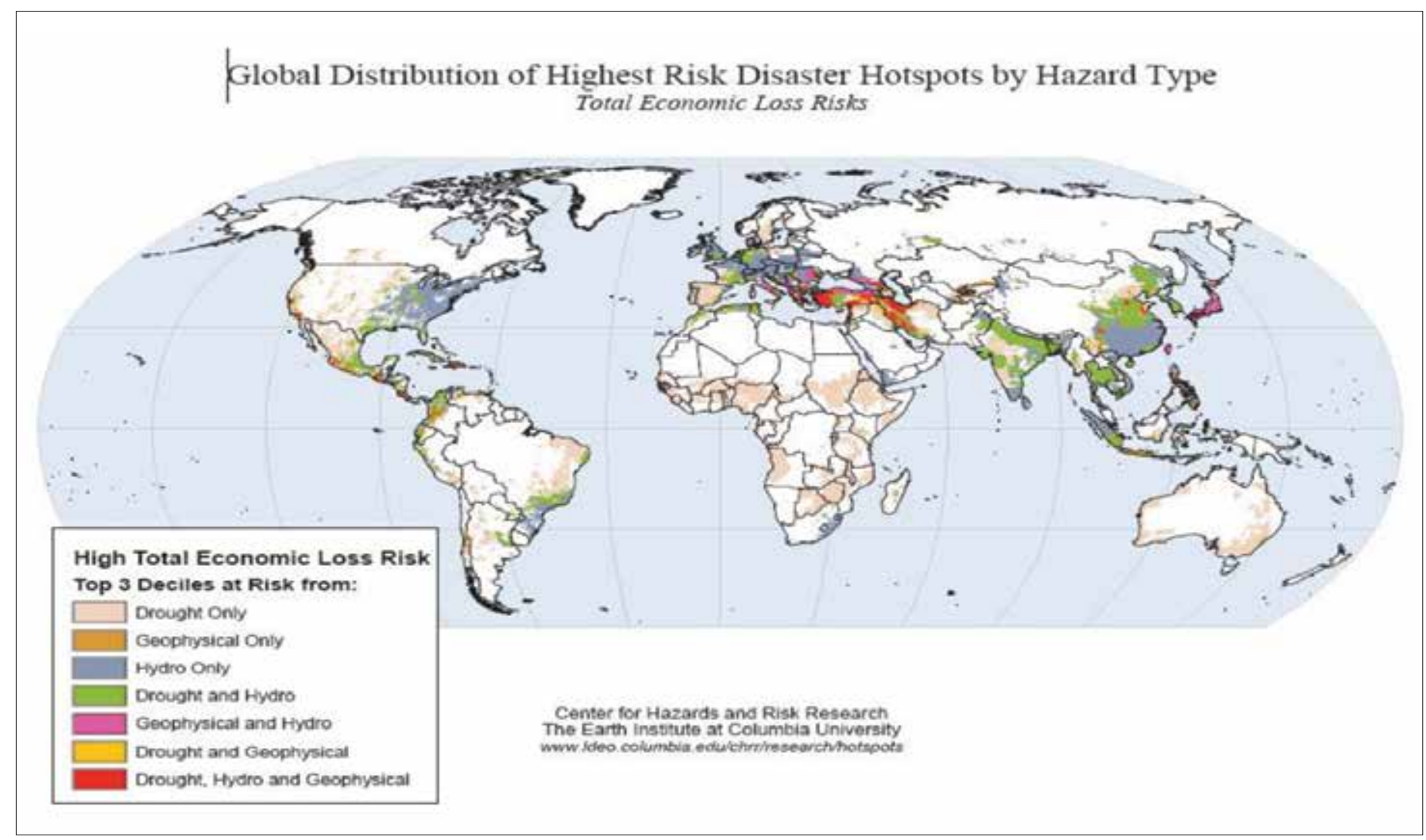

Figure 1. Map Sample for Global Disaster Hotspots Project

Reference: Westen Cv, Alkema D, Damen M, Kerle N, Kingma N. 2011. Multi-hazard risk assessment: Distance education course Guide book, United Nations University. Tokyo. 
countered by the society in the case that a potential disaster occurs (10). Specifically, vulnerability is the level of resistance against a disaster. Vulnerability is a phenomenon that may be used in a large field and at different levels. Vulnerability is also considered an environmental hazard, while it is considered as a common product of fragility, security flaw, exposure, and stress. This term has been revealed as a set of terms, such as overlapping sensitiveness, resistance, flexibility, marginality, fragility, and security flaw. O'Keefe (1976) first used the term "vulnerability" with respect to the disasters, while investigating the key role played by the effects of excess geophysical events, rescue, and socioeconomic factors, which led to an intervention failure (11). In the late 1980 s and in the early 1990s, two conceptual models were developed to offer a frame for the disaster managers to understand the vulnerability against disasters and reduce it. The first one is a capacity and vulnerability analysis and the second one is a pressure and release model (12). Although the vulnerability is differently perceived by different people, factors and components thereof are classified differently (13). The concept of vulnerability in this study was used as a measurement of resistance capacity of different regions having different economies and disaster reasons against the disasters.

The aim of the vulnerability analysis was to define a suitable activity that can reduce the vulnerability before a damage arising from the potential dangers occurs (14). One of the biggest benefits of vulnerability analysis for different regions is to guide the policy implementers of the government for distributing relief funds to be obtained for these regions and to improve the capacities of these regions to resist against the disasters (11). Vulnerability may be expressed in different ways by performing a vulnerability analysis, such as vulnerability indices, vulnerability curves, fragility curves, and vulnerability tables (15).

A literature review indicated that various studies have been conducted using the Data Envelopment Analysis (DEA) method. For natural disasters in 31 regions of China, effect indices and regional vulnerability indices were obtained using the DEA method in 2004 (11). In this study, DEA and regional vulnerability indices were calculated using economic and social costs experienced in a period of quarter century in Turkey. Thus, the objective of the study was to obtain vulnerability indices of different regions for the disasters socially and economically in Turkey as part of disaster preparedness and risk management. Thereby, another objective of the study was to guide decision makers, policymakers, strategists, and implementers working in the field.

\section{A DEA-Based Model for Evaluating Relative Effect Intensity of Natural Disasters}

Features of decision-making units (DMUs) are combined and a "virtual" DMU or region is created using this method to visualize the DMUs. The weights to be used for visualizing the DMUs are selected such that an efficiency value for these units (or a disaster effect index) is maximized. There is a relevant linear programming model for each region considered, as in the following (16):
Minimize $Q\left(i_{0}\right)$ subject to,

$$
\begin{aligned}
& \sum_{i=1}^{n} \lambda_{i}\left(i_{0}\right) \chi^{1}(i) \leq \chi^{1}\left(i_{0}\right) \\
& \sum_{i=1}^{n} \lambda_{i}\left(i_{0}\right) \chi^{2}(i) \leq \chi^{2}\left(i_{0}\right) \\
& \sum_{i=1}^{n} \lambda_{i}\left(i_{0}\right) y^{2}(i) \geq y^{1}\left(i_{0}\right) \\
& \sum_{i=1}^{n} \lambda_{i}\left(i_{0}\right) y^{2}(i) \geq y^{2}\left(i_{0}\right) \\
& \quad \lambda_{i}\left(i_{0}\right) \geq 0 \\
& 0<Q\left(i_{0}\right) \leq 1
\end{aligned}
$$

Where in $\chi^{1}(i)$ indicates GDP of $i^{\text {th }}$ region; $\chi^{2}$ (i) indicates total population of $i^{\text {th }}$ region $(i=1,2, \ldots, n) ; y^{1}(i)$ indicates total economic loss of $i^{\text {th }}$ region arising from the disasters; and $y^{2}$ (i) indicates total population of $i^{\text {th }}$ region affected by the disasters. In addition $i_{0}$ is the evaluated region; $\lambda_{i}\left(i_{0}\right)$ $(i=1,2, \ldots, n)$ is the evaluated region; and $i_{0}^{\text {th }}$ region is the weight of $i^{\text {th }}$ region.

Subsequently, $Q\left(i_{0}\right)$ shows relative intensity of the disaster for the region $i_{0}$. This value is always $Q\left(i_{0}\right) \leq 1$ and if $Q\left(i_{0}\right)=1$ for the region $i_{0}$, indicating that this region has been affected from the disaster most intensely. A low value indicates that the region has been effected mildly. $Q\left(i_{0}\right)$ is used as "activity" in DEA literature, while it is used as "intensity index for disasters" in this study. DEA separates the inputs and outputs, for example, it does not arbitrarily decide on relative contribution of human loss on loss of property. Thus, there is a sum of $n$ models for the regions $i_{0}=0.1, \ldots, n$. When all these linear programming models are encoded, we thereby calculate the intensity index of the natural disasters for all $\mathrm{n}$ regions.

\section{Calculation of Regional Vulnerability Indices Using Relative Effect Intensity of Natural Disasters}

With the previous model, disaster intensity indices of the regions were calculated in accordance with years. However, a combined intensity index of the regions was also calculated; the vulnerability index of each region is thus obtained. Here to calculate vulnerability index of $\mathrm{n}$ region, effect intensity indices in each period should be considered. In this study, arithmetic averages of the calculated effect intensity indices in accordance with the number of periods were calculated, thereby vulnerability indices of these regions were calculated. For t. year of first region among $\mathrm{N}$ regions, when the effect intensity index $(t=1,2, \ldots, T)$ is $Q(i, t)$ and the number of assessed period is T, then the vulnerability index of the first region is $\emptyset(i)=1 / T \Sigma_{t=1}^{T} Q(i, t)$.

\section{Materials and Methods}

In the study, data of disasters occurred in Turkey between 1987 and 2011 were used. Earthquake, flood, landslip, fire, avalanche, and refugee invasion events were regarded as disaster types. Data relating to disasters 
Table 1. Vulnerability Indices of Natural Disasters Occurred in 26 Regions of Turkey between $1987-1999$ ( $1^{\text {st }}$ Period) as Calculated Using DEA

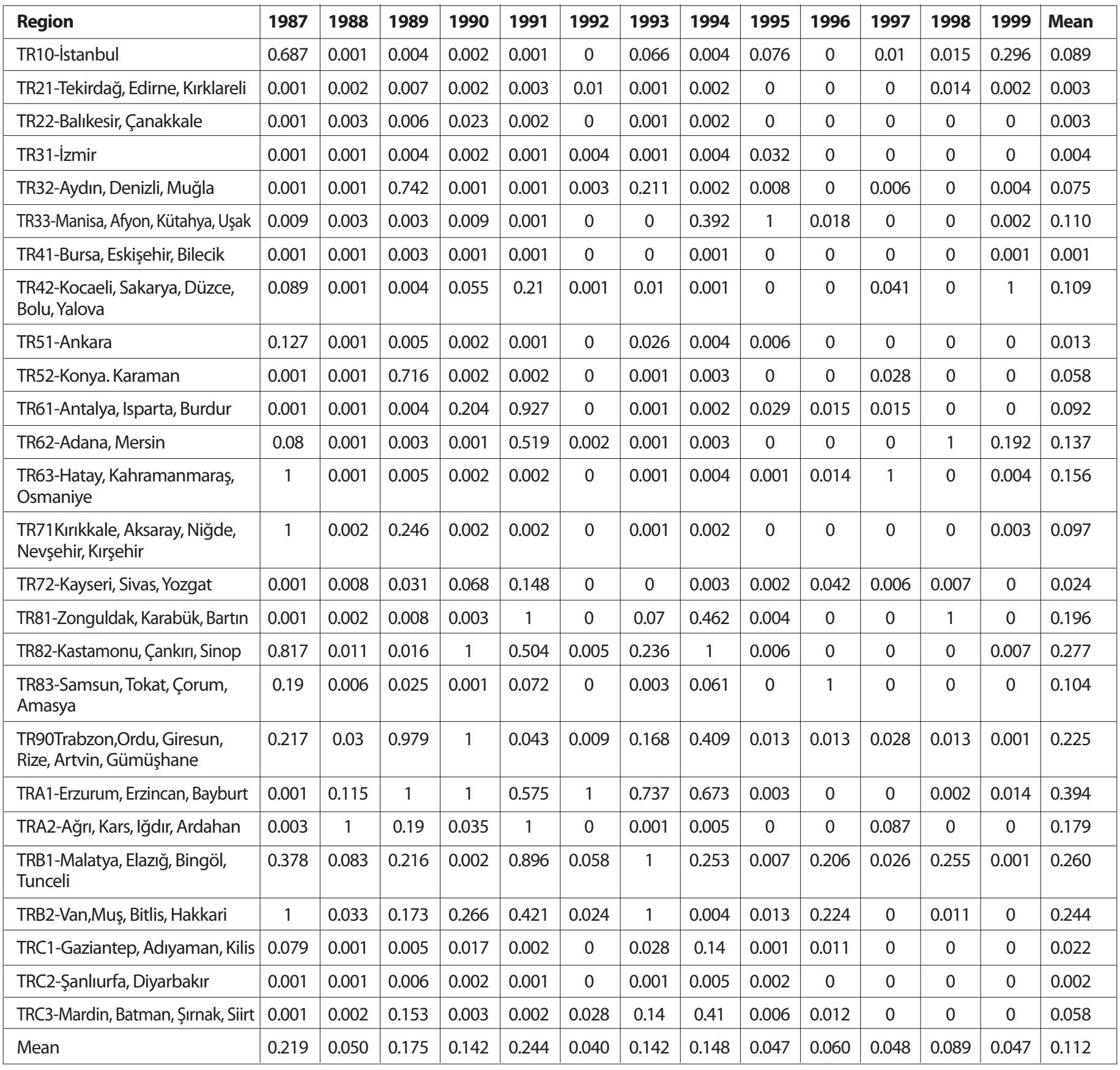

were obtained from annual activity reports of TDDB and T.R. Red Crescent of previous years (17). Data relating to country population and GDP of the regions were obtained from national statistics departments with population and demography published in the official website of Turkey Statistical Institute (TÜIK) (18). The population belonging to the years when population census was not conducted for regional population was determined by averaging of the next and the previous population numbers. Moreover, 2002 and 2003 region-specific missing GDP data were also obtained by averaging the next and the previous years' data. The study was applied on 26 regions as published by regional GDP values of TÜiK.

In the study, vulnerability indices of the disasters were calculated using the DEAP 2.1 program with data envelopment analysis-based, output-oriented Malmquist Total Productivity Index method. Total population and total GDP of the regions were used as inputs; total number of population affected from the disasters in that region and total economic loss incurred by the disasters were used as outputs in the method. This study was prepared in accordance with the Helsinki Declaration.

\section{Results}

The vulnerability indices and economic data of 26 regions of Turkey obtained from the study are explained below in the form of tables.

According toTable 1 andTable2, when arithmeticaveragevalues of thevulnerabilityindicesoftheregionsareexamined,thisvaluewas 0.112 for 1987-1999 (first period) and 0.113 for 1999-2011 (second period). 
Table 2. Vulnerability Indices of Natural Disasters Occurred in 26 Regions of Turkey between 2000-2011 (2 ${ }^{\text {nd }}$ Period) as Calculated Using DEA

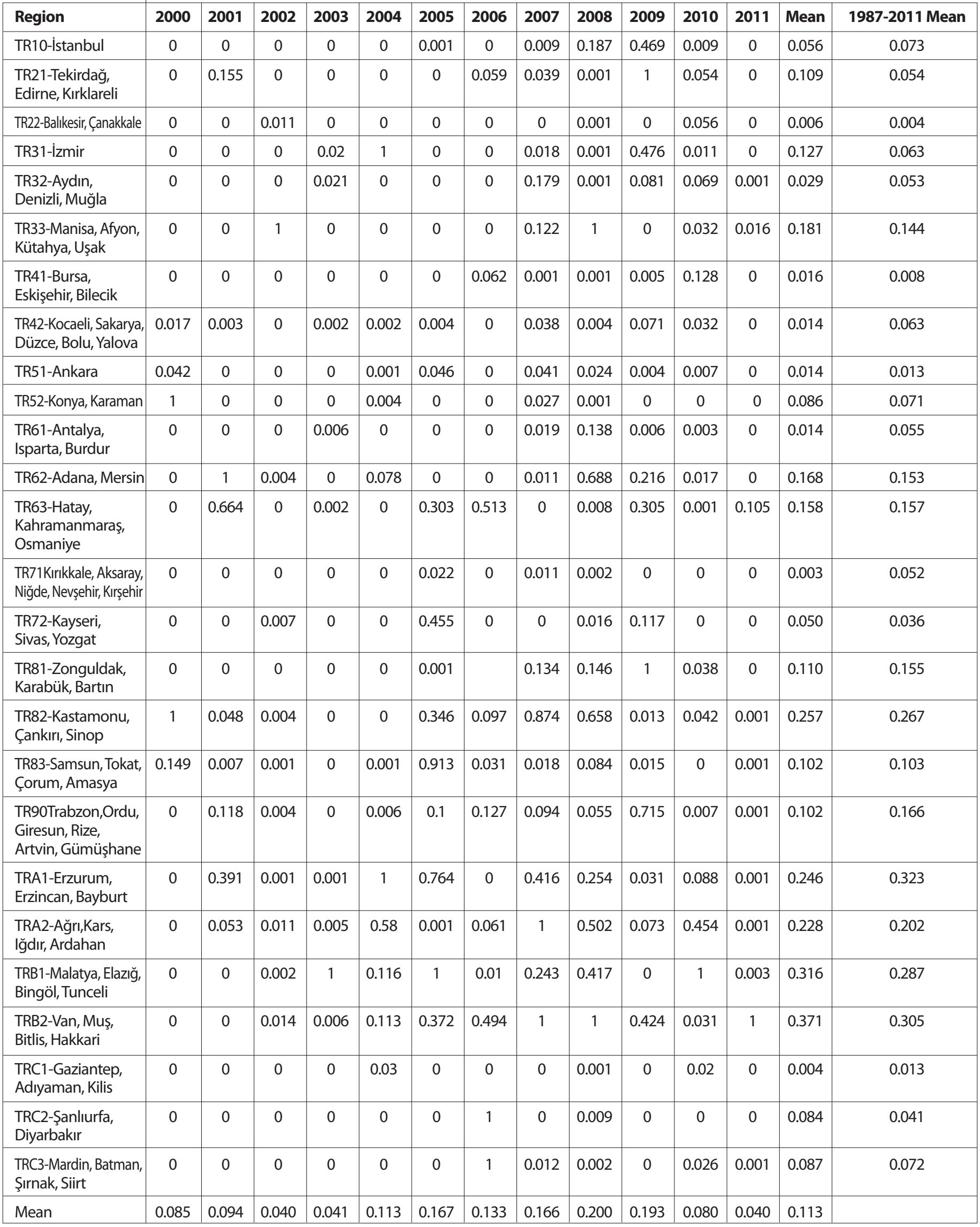




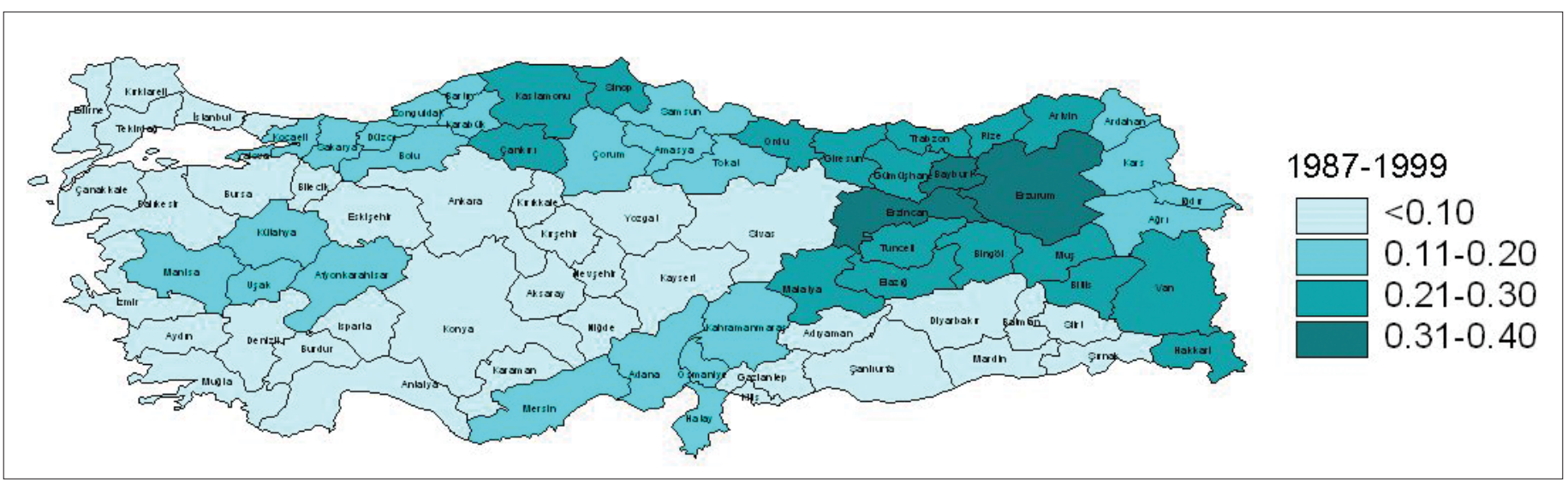

Figure 2. Vulnerability Index Map of Turkey Regions between the years 1987-1999

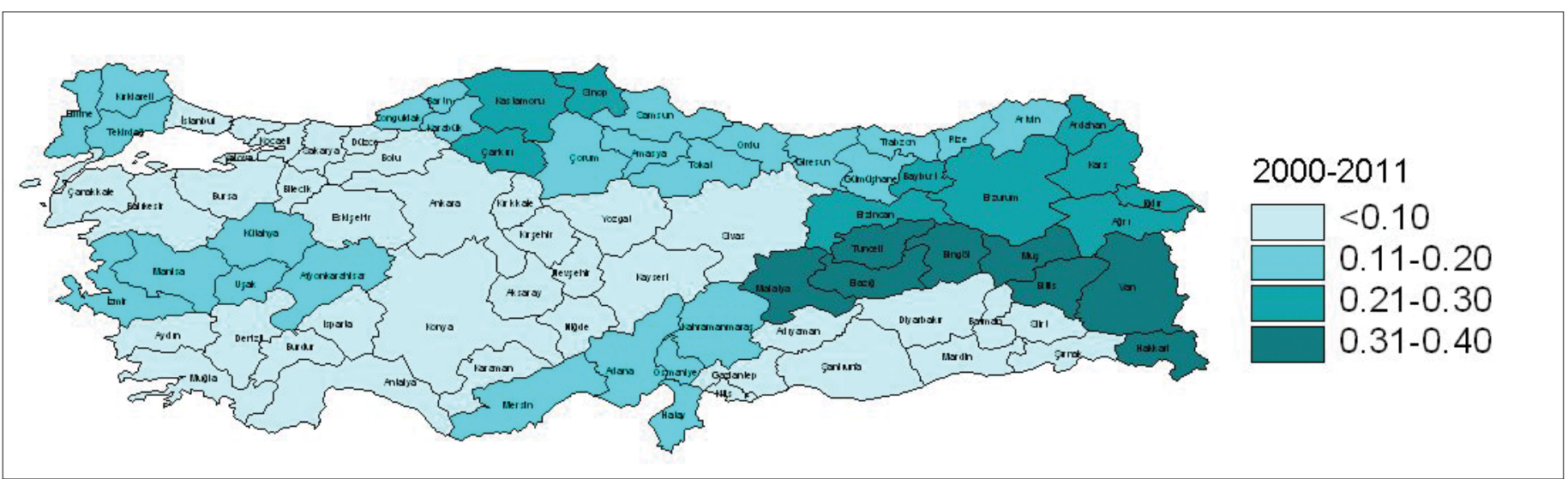

Figure 3. Vulnerability Index Map of Turkey Regions between the years 2000-2011

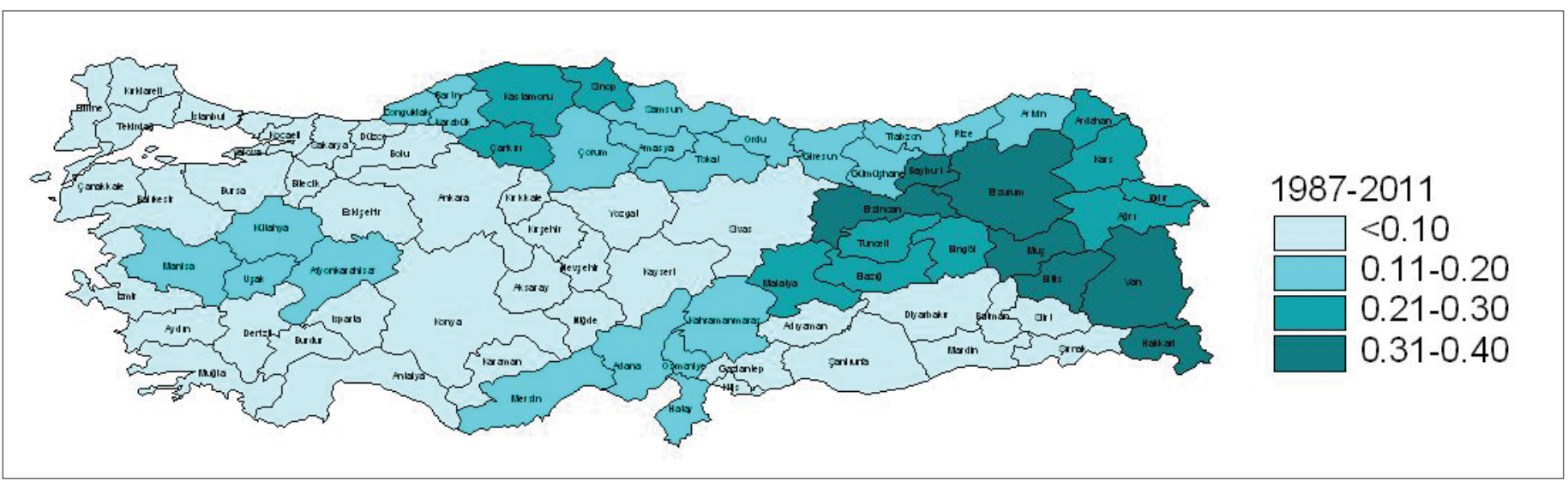

Figure 4. Vulnerability index Map of Turkey Regions between the years 1987-2011

Thus, the vulnerability index averages of the regions were slightly higher in the second period. When total averages of the vulnerability indices of the regions were considered, the regions with the highest value in the first period were TRA1, TRB2, and TRB1 regions. In the second period, the regions with the highest vulnerability indices are TRB2 (0.371), TRB1 (0.316), and TR82 (0.257). It was noted that there is a differentiation in terms of regions in the first and second periods.

When vulnerability indices of the years were examined over the averages, it was noted that 1991 (0.244), 1987 (0.219), and 1989 (0.175) stand out in the first period and averages of 2008 (0.200), 2009 (0.193), and 2007 (0.166) years are high in the second period.
When Figure 2 is examined, the regions with the highest vulnerability for 1987-1999 are noted generally in Eastern Anatolia and Eastern Black Sea Regions. The reason is that flood and landslide disasters are common in Eastern Black Sea Region, and flood, landslide, avalanche, and earthquake disasters are common in Eastern Anatolia Region. Moreover, the Central Black Sea section of Black Sea Region was noted to have high vulnerability index due to the intensity of floods and landslides along with frequent bush fire disasters in Kastamonu Province. In the west of the country, Afyonkarahisar and Kütahya were noted to be among the most intense regions in terms of vulnerability. 


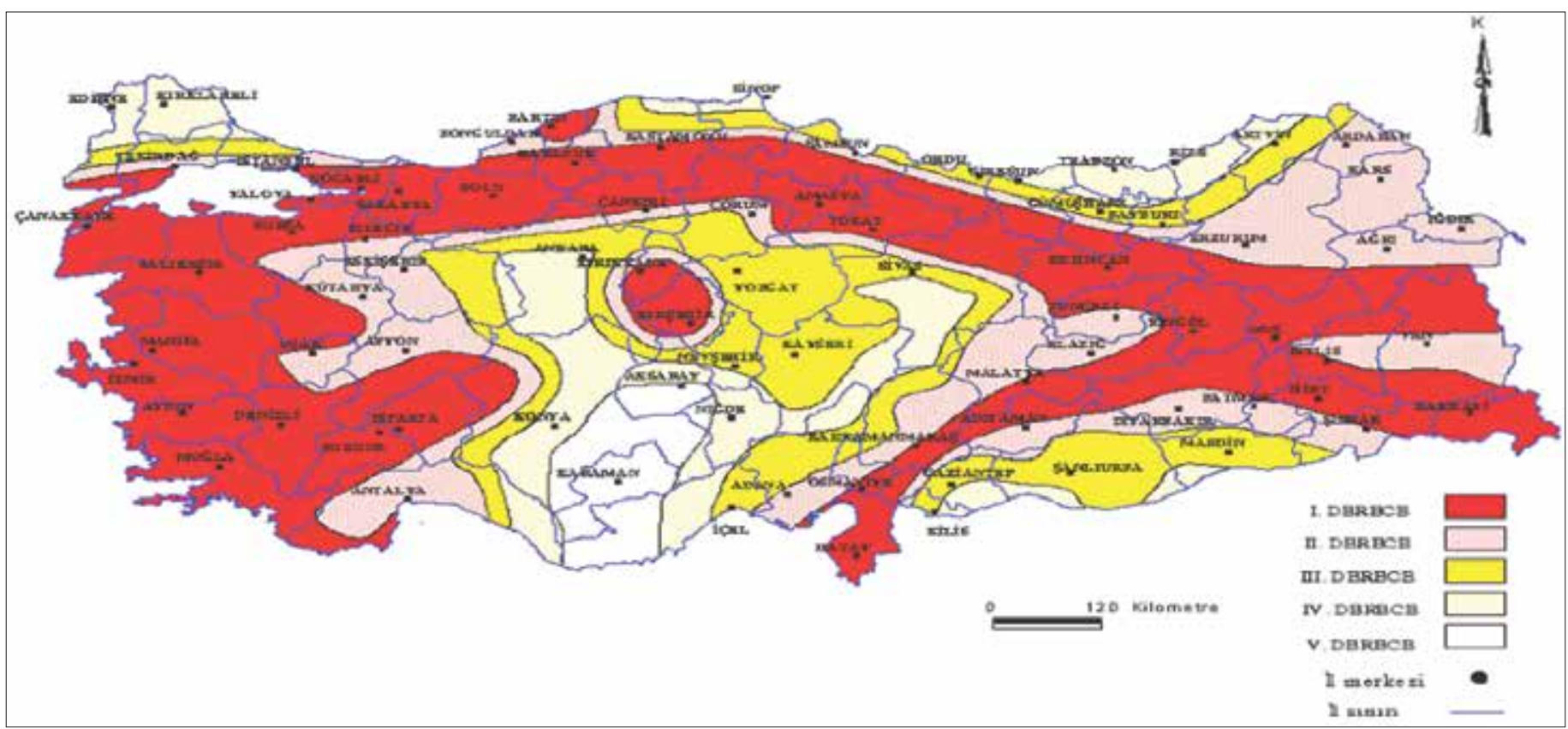

Figure 5. Map of Turkey Earthquake Regions

Reference: http://www.e-sehir.com/turkiye-haritasi/deprem-fay-haritasi.php

According to Figure 3, although the vulnerability index intensity of the regions for 2000-2011 shows similarity with Figure 2, the regions with the highest intensities are the southern zones of Eastern Anatolia Region. In addition, the intensity of the Eastern Black Sea Region was decreased with respect to the previous period. In this period, the Central Black Sea Region has a similar intensity with the previous period. In the west, the intensity is expanded by incorporating Trakya Region.

When total index map of all periods were examined, it was seen that the intensity generally contains Eastern Anatolia Region of the country. Moreover, the intensity was in the same regions in the central zone of the Black Sea Region. The intensity in the western zones was noted to increase in the internal zones of Aegean Region (Figure 4).

Although the study contains general disaster types, according to the vulnerability index map, the places with the highest intensity in terms of vulnerability is noted to overlap with the regions containing the Northern Anatolia Fault Line in the north, and the Eastern Anatolia Fault Line in the east. Moreover, it is noticed that the region containing Western Anatolia Fault Line in Aegean Region has similar high intensity in terms of vulnerability. According to the maps of vulnerability index, it is understood that the regions with the highest vulnerability in Turkey are the first-degree earthquake regions. From this aspect, it may be suggested that the vulnerability maps show similarity with the earthquake map of Turkey (Figure 5).

Based on Table 3, TRB2 region (1987, 1993, 2007, 2008, and 2011), we noticed that on five occasions, the vulnerability index was 1.0. Besides, as for TRB1 region (1993, 2003, 2005, and 2010), it was noticed that the vulnerability indexes were equal to 1 in a total of four occasions. For the TRA1 region (1989, 1992, and 2004), TR82 region (1990, 1994, and 2000), TR33 region (1995, 2002, and 2008), and TR81 regions (1991, 1998, and 2009), it was noticed that the vulnerability indexes were equal to 1 in three occasions. The vulnerability index is equal to 1 in two occasions in the TR63 (1987 and 1997) and TRA2 and TR62 regions (1988 and 1991).
Regions are classified according to their vulnerability indices, as shown in Table 4. According to this classification, Turkey's regions with the highest vulnerability index values (range, 0.31-0.40) are TRA1 (0.323) and TRB2 (0.305). While according the results of Table 1, one of the three regions with the highest vulnerability index (TRA1) can also be seen as the highest on Table 4. One of the three regions (TRB2) with the highest impact force index according to Table 2 is also of the highest vulnerability according to Table 4. According to the vulnerability index values, the country's most fragile regions are TRA1 (0.323), while the least fragile is the TR22A (0.004).

From the aspect of the economic losses caused by natural disasters, the average annual economic losses are highest in TR42-Kocaeli, Sakarya, Düzce, Bolu, Yalova, followed by TRB2-Van, Mus, Bitlis, Hakkari, TR71-Kırıkkale, Aksaray, Nigde, Nevsehir, Kırşehir, TR63-Hatay, Kahramanmaras, Osmaniye, TRB1-Malatya, Elazığ, Bingöl, Tunceli, TR10-Istanbul, TR33-Manisa, Afyon, Kutahya, and Usak regions. The average rate of economic losses as a percentage of GDP are highest in TRB2-Van, Mus, Bitlis, Hakkari, followed by TR42-Kocaeli, Sakarya, Düzce, Bolu, Yalova, TR71-Kırıkkale, Aksaray, Nigde, Nevsehir, Kırşehir, TRB1-Malatya, Elazığ, Bingöl, Tunceli, TR63-Hatay, Kahramanmaraş, and Osmaniye regions (Table 5).

\section{Discussion}

On an average, the vulnerability indices obtained for the regions of Turkey in the two periods 1987-1999 (first period) and 2000-2011 (second period) were discussed. When vulnerability index averages for both periods were considered, the second period average was slightly higher than the first period average. This result appears to support the idea that the disasters in Turkey have generally an increasing trend after the year 2000 with respect to the studies previously conducted.

In a similar study, Wei and colleagues obtained vulnerability indices of different regions of China in 2004. In the study conducted by 
Table 3. Regions Affected Most Intensely from Disasters for Each Year between the years 1987-2011 (Regions with Vulnerability index equaling to 1)

\begin{tabular}{|c|c|}
\hline Years & DMU \\
\hline \multirow[t]{3}{*}{1987} & TR63-Hatay, Kahramanmaraş, Osmaniye \\
\hline & TR71-Kırıkkale, Aksaray, Niğde, Nevşehir, Kırşehir \\
\hline & TRB2-Van, Muş, Bitlis, Hakkari \\
\hline 1988 & TRA2-Ağrı, Kars, Iğdır, Ardahan \\
\hline 1989 & TRA1-Erzurum, Erzincan, Bayburt \\
\hline 1990 & TR82-Kastamonu, Çankırı, Sinop \\
\hline \multirow[t]{2}{*}{1991} & TR81-Zonguldak, Karabük, Bartın \\
\hline & TRA2-Ağrı, Kars, Iğdır, Ardahan \\
\hline 1992 & TRA1-Erzurum, Erzincan, Bayburt \\
\hline \multirow[t]{2}{*}{1993} & TRB1-Malatya, Elazığ, Bingöl, Tunceli \\
\hline & TRB2-Van, Muş, Bitlis, Hakkari \\
\hline 1994 & TR82-Kastamonu, Çankırı, Sinop \\
\hline 1995 & TR33-Manisa, Afyon, Kütahya, Uşak \\
\hline 1996 & TR83-Samsun, Tokat, Çorum, Amasya \\
\hline 1997 & TR63-Hatay, Kahramanmaraş, Osmaniye \\
\hline \multirow[t]{2}{*}{1998} & TR62-Adana, Mersin \\
\hline & TR81-Zonguldak, Karabük, Bartın \\
\hline 1999 & TR42-Kocaeli, Sakarya, Düzce, Bolu, Yalova \\
\hline \multirow[t]{2}{*}{2000} & TR52-Konya, Karaman \\
\hline & TR82-Kastamonu, Çankırı, Sinop \\
\hline 2001 & TR62-Adana, Mersin \\
\hline 2002 & TR33-Manisa, Afyon, Kütahya, Uşak \\
\hline 2003 & TRB1-Malatya, Elazığ, Bingöl, Tunceli \\
\hline \multirow[t]{2}{*}{2004} & TR31-İzmir \\
\hline & TRA1-Erzurum, Erzincan, Bayburt \\
\hline 2005 & TRB1-Malatya, Elazığ, Bingöl, Tunceli \\
\hline \multirow[t]{2}{*}{2006} & TRC2-Şanlıurfa, Diyarbakır \\
\hline & TRC3-Mardin, Batman, Şırnak, Siirt \\
\hline \multirow[t]{2}{*}{2007} & TRA2-Ağrı, Kars, Iğdır, Ardahan \\
\hline & TRB2-Van, Muş, Bitlis, Hakkari \\
\hline \multirow[t]{2}{*}{2008} & TR33-Manisa, Afyon, Kütahya, Uşak \\
\hline & TRB2-Van, Muş, Bitlis, Hakkari \\
\hline \multirow[t]{2}{*}{2009} & TR21-Tekirdağ, Edirne, Kırklareli \\
\hline & TR81-Zonguldak, Karabük, Bartın \\
\hline 2010 & TRB1-Malatya, Elazığ, Bingöl, Tunceli \\
\hline 2011 & TRB2-Van, Muş, Bitlis, Hakkari \\
\hline
\end{tabular}

Wei and colleagues, 31 regions comprising the whole of China were discussed, and disaster data for 1989-2000 were used as data of the study. In this study, 26 regions containing the whole Turkey and the disaster data for 1987-2011 were used as data. Moreover, in the study
Table 4. Vulnerability Classification of Regions of Turkey over Averages on Basis of Vulnerability Index

\begin{tabular}{|c|c|}
\hline $\begin{array}{l}\text { Vulnerability } \\
\text { index }\end{array}$ & Region \\
\hline \multirow[t]{13}{*}{$<0.10$} & TR22-Balıkesir, Çanakkale (0.004), \\
\hline & TR41-Bursa, Eskişehir, Bilecik (0.008), \\
\hline & TR51-Ankara (0.013), \\
\hline & TRC1-Gaziantep, Adıyaman, Kilis (0.013), \\
\hline & TR72-Kayseri, Sivas, Yozgat (0.036), \\
\hline & TRC2-Şanlıurfa, Diyarbakır (0.041) \\
\hline & $\begin{array}{c}\text { TR71-Kırıkkale, Aksaray, Niğde, Nevşehir, } \\
\text { Kırşehir (0.052), }\end{array}$ \\
\hline & TR61-Antalya, Isparta, Burdur (0.055), \\
\hline & TR52-Konya, Karaman (0.071), \\
\hline & TRC3-Mardin, Batman, Şırnak, Siirt (0.072) \\
\hline & TR21-Tekirdağ, Edirne, Kırklareli (0.080), \\
\hline & TR32-Aydın, Denizli, Muğla (0.080), \\
\hline & TR42-Kocaeli, Sakarya, Düzce, Bolu, Yalova (0.080) \\
\hline \multirow[t]{8}{*}{$0.11-0.20$} & TR83-Samsun, Tokat, Çorum, Amasya (0.103), \\
\hline & TR31-İzmir (0.110), \\
\hline & TR10-İstanbul (0.120), \\
\hline & TR33-Manisa, Afyon, Kütahya, Uşak (0.144), \\
\hline & TR62-Adana, Mersin (0.153), \\
\hline & TR81-Zonguldak, Karabük, Bartın (0.155) \\
\hline & TR63-Hatay, Kahramanmaraş, Osmaniye (0.157), \\
\hline & $\begin{array}{c}\text { TR90-Trabzon, Ordu, Giresun, Rize, Artvin, } \\
\text { Gümüşhane (0.166) }\end{array}$ \\
\hline \multirow[t]{3}{*}{$0.21-0.30$} & TRA2-Ağrı, Kars, Iğdır, Ardahan (0.202), \\
\hline & TR82-Kastamonu, Çankırı, Sinop (0.267), \\
\hline & TRB1-Malatya, Elazığ, Bingöl, Tunceli (0.287) \\
\hline \multirow[t]{2}{*}{$0.31-0.40$} & TRB2-Van, Muş, Bitlis, Hakkari (0.305), \\
\hline & TRA1-Erzurum, Erzincan, Bayburt (0.323) \\
\hline \multicolumn{2}{|l|}{$0.41-0.50$} \\
\hline$>0.50$ & \\
\hline
\end{tabular}

conducted for China, the vulnerability index table was shown with only one table due the presence of less number of periods, while two tables were shown as the 1987-1999 period and the 2000-2011 period in this study. Thus, the comparison of both periods became possible. In the study conducted by Wei et al. (11), the regions with disaster effect intensity index equaling to 1 were gathered in 1989 (six regions) at most, while in 1987 (three regions) in this study. In the classification of the vulnerability indices, regions were gathered in the range of $0.41-0.50$ at most (13 regions), while regions were gathered in the range of $0-0.10$ at most (nine regions) in this study. In the study conducted in 2004, the vulnerability indices of three regions with the highest vulnerability index were, respectively, 0.52, 0.60 , and 0.62 , while in this study, the vulnerability indices of three 
Table 5. Average Annual Economic Losses Resulting from Disasters of Regions between the years 1987-2011

\begin{tabular}{|c|c|c|}
\hline Region & $\begin{array}{l}\text { Average annual } \\
\text { economic losses } \\
\text { (million TL) }\end{array}$ & $\begin{array}{c}\text { Average economic } \\
\text { losses as } \\
\text { a percentage } \\
\text { of GDP }\end{array}$ \\
\hline TR10-İstanbul & 17.980 & $0.024 \%$ \\
\hline $\begin{array}{l}\text { TR21-Tekirdağ, Edirne, } \\
\text { Kırklareli }\end{array}$ & 0.038 & $0.0004 \%$ \\
\hline TR22-Balıkesir, Çanakkale & 0.010 & $0.0002 \%$ \\
\hline TR31-İzmir & 0.110 & $0.0006 \%$ \\
\hline TR32-Aydın, Denizli, Muğla & 0.150 & $0.001 \%$ \\
\hline $\begin{array}{l}\text { TR33-Manisa, Afyon, } \\
\text { Kütahya, Uşak }\end{array}$ & 5,562 & $0,05 \%$ \\
\hline $\begin{array}{l}\text { TR41-Bursa, Eskişehir, } \\
\text { Bilecik }\end{array}$ & 0.026 & $0.0001 \%$ \\
\hline $\begin{array}{l}\text { TR42-Kocaeli, Sakarya, } \\
\text { Düzce, Bolu, Yalova }\end{array}$ & 427.809 & $2.3 \%$ \\
\hline TR51-Ankara & 0.040 & $0.0002 \%$ \\
\hline TR52-Konya, Karaman & 0.212 & $0.003 \%$ \\
\hline TR61-Antalya, Isparta, Burdur & 0.141 & $0.001 \%$ \\
\hline TR62-Adana, Mersin & 0.775 & $0.006 \%$ \\
\hline $\begin{array}{l}\text { TR63-Hatay, } \\
\text { Kahramanmaraş, } \\
\text { Osmaniye }\end{array}$ & 21.405 & $0.3 \%$ \\
\hline $\begin{array}{l}\text { TR71-Kırıkkale, Aksaray, } \\
\text { Niğde, Nevşehir, Kırşehir }\end{array}$ & 34.736 & $0.6 \%$ \\
\hline TR72-Kayseri, Sivas, Yozgat & 0.041 & $0.0005 \%$ \\
\hline $\begin{array}{l}\text { TR81-Zonguldak, Karabük, } \\
\text { Bartın }\end{array}$ & 0.644 & $0.013 \%$ \\
\hline $\begin{array}{l}\text { TR82-Kastamonu, } \\
\text { Çankırı, Sinop }\end{array}$ & 0.257 & $0.009 \%$ \\
\hline $\begin{array}{l}\text { TR83-Samsun, Tokat, } \\
\text { Çorum, Amasya }\end{array}$ & 0.280 & $0.003 \%$ \\
\hline $\begin{array}{l}\text { TR90-Trabzon, Ordu, } \\
\text { Giresun, Rize, Artvin, } \\
\text { Gümüşhane }\end{array}$ & 0.446 & $0.005 \%$ \\
\hline $\begin{array}{l}\text { TRA1-Erzurum, Erzincan, } \\
\text { Bayburt }\end{array}$ & 1.979 & $0.06 \%$ \\
\hline $\begin{array}{l}\text { TRA2-Ağrı, Kars, lğdır, } \\
\text { Ardahan }\end{array}$ & 0.384 & $0.016 \%$ \\
\hline $\begin{array}{l}\text { TRB1-Malatya, Elazığ, } \\
\text { Bingöl, Tunceli }\end{array}$ & 20.589 & $0.4 \%$ \\
\hline $\begin{array}{l}\text { TRB2-Van, Muş, Bitlis, } \\
\text { Hakkari }\end{array}$ & 80.576 & $2.4 \%$ \\
\hline $\begin{array}{l}\text { TRC1-Gaziantep, } \\
\text { Adıyaman, Kilis }\end{array}$ & 0.058 & $0.001 \%$ \\
\hline TRC2-Şanlıurfa, Diyarbakır & 0.354 & $0.006 \%$ \\
\hline $\begin{array}{l}\text { TRC3-Mardin, Batman, } \\
\text { Şırnak, Siirt }\end{array}$ & 0.338 & $0.008 \%$ \\
\hline General mean & 23.652 & $0.239 \%$ \\
\hline
\end{tabular}

regions with the highest vulnerability index were, respectively, 0.33 , 0.36 , and 0.38 .

Cardona performed an implementation of an indicator system in the USA within the scope of disaster risk management with a different method in 2004 and collected Disaster Deficit Index, Local Disaster Index, Prevalent Vulnerability index (PVI), and Risk Management Index values of the regions (19). In a section of the study conducted, ratio of the economic losses to the GDP and socioeconomic vulnerability of 12 regions of the USA over the society exposed to the disasters were calculated. These vulnerability values were separately calculated for the years 1985, 1990, 1995, and 2000 over 100 full points, for example, socioeconomic vulnerability values of different regions for the year 2000 were found in the range of 20-62. Bollin and Hidajat (20) calculated danger, exposure, vulnerability, capacity, and risk indices of some regions of Indonesia within the scope of society-based disaster risk index with a different method in the year 2006. In this study, index values of two regions called as Sikka and Kulon Progo were compared. The index values were calculated over 100 points, and the vulnerability indices were 21 for two regions, while the risk indices were respectively obtained as 56 and 54 . In a study conducted for Barbados in 2010, the PVI values of the country for the years $1985,1990,1995,2000,2005$, and 2007 were obtained. According to the results found, common vulnerability index values of this country had values ranging from 39.342 to 45.493 (21).

Moreover, in a study conducted by Birkmann in (22) 2007, applications for obtaining risk and vulnerability indices using different scales were compared. At the end of the study, there is a need of more researches and studies relating to this subject for learning environmental security flaws, learning how to increase medium- and long-term flexibility for natural and sudden dangers, and discovering institutional and environmental vulnerabilities. In a study conducted on Turkey provinces by Ozceylan and Coskun in (23) 2012, socioeconomic vulnerability indices of the provinces in terms of earthquake were determined. The provinces with socially and economically the highest vulnerability as a result of this study were Şanlıurfa, Şırnak, Hakkari, Siirt, Batman, Van, Gaziantep, Ağrı, Mardin, and Diyarbakır. On comparison of two studies in terms of the highest values, Van and Hakkari were the overlapping provinces.

\section{Conclusion}

The DEA method is known to be applicable in a variety of fields and enables the achievement of a single value over interaction of a number of variables. The single value obtained enables the researchers to make comparisons among units, regions, and/or classifications. The feature of the model for being used effectively popularizes the use of the model.

In this study, the DEA method enabled the conversion of economic and social costs as a result of disasters in 26 regions of Turkey to vulnerability indices. A picture of the whole country over a period of 25 years in terms of disasters was captured. In the picture, economic and social costs endured due to disasters are noted to be separated into two regions starting from the region of Eastern Anatolia and the north branch extends across the Black Sea region and the other south branch reaches to the Mediterranean. Moreover, the presence of an area as an inlet in the Aegean Region is observed. The Central Anatolia, Southeastern Anatolia, Marmara, and partially the Aegean Region may said to be exposed to disasters losses. 
The fact that Turkey vulnerability index maps obtained overlap with the Turkey earthquake map, the Earth disaster map may be regarded as a confirmation of the reliability of the study results.

The 1999 Kocaeli and 2011 Van earthquakes stand out in terms of economic losses; it is seen that Van and Erzincan regions have the highest vulnerability index in terms of earthquakes, and the Black Sea region is an important disaster area in terms of floods, landslips. and deluges. It is suggested that the vulnerability indices provided for Turkey are used in region- and province-level arrangements; in organizational structure, logistic and human resources planning and development; and in improvement of risk analysis, strategic planning and management applications by Prime Ministry Disaster and Emergency Management Authority (AFAD) being a new organization in Turkey. Moreover, it is thought that these study results shall form a ground for policymakers and resource allocation managers, shall guide the applicators in the field, and shall lead to information production studies in the field of disaster management.

Ethics Committee Approval: Authors declared that the research was conducted according to the principles of the World Medical Association Declaration of Helsinki "Ethical Principles for Medical Research Involving Human Subjects", (amended in October 2013)

Informed Consent: Patient approval was not obtained because patient information was not used in this study.

Peer-review: Externally peer-reviewed.

Acknowledgements: We thank Assoc. Prof. Fatih Döner (PhD) department of Map Engineering Gümüşhane University for drawing maps.

Conflict of Interest: No conflict of interest was declared by the authors.

Financial Disclosure: The authors declared that this study has received no financial support.

\section{References}

1. Tanyas M, Gunalay Y, Aksoy L, Kucuk B. Disaster Logistics Management: A New Model Proposal for Rize (Turkish). In: II. Rize Development Symposium Proceedings (Saime CB, Emre Y, eds) Rize: Recep Tayyip Erdogan University 2013: 4: 256-8.

2. Gokce O, Ozden S, Demir A. Spatial and Statistical Distribution of Disasters in Turkey; Disaster Information Inventory (Turkish) (Ankara: Republic of Turkey Ministry of Public Works and Settlement General Directorate of Disaster Affairs and Disaster Damage Assessment Studies Department, 2008).

3. Yaprak U. Data Analysis for Inventory Control In Disaster Logistics (Turkish) [Master's Thesis] (Gumushane: Gumushane University Institute of Social Sciences, 2015).

4. Pindyck RS, Wang N. The Economic and Policy Consequences of Catastrophes. National Bureau of Economic Research 2009; NBER Working Paper 15373: 1-42.

5. Borenszteın E, Cavallo E, Valenzuela P. Dept Sustainability Under Catastrophic Risk: The Case For Goverment Budget Insurance 2008; IMF Working Paper WP/08/44: 2-26.

6. Cavallo E, Galiani S, Noy I, Pantano J. Catastrophic Natural Disasters and Economic Growth. IDB Working Paper Series No. IDB-WP-183 (2010).
7. Akar S. The Impact of Natural Disasters on Public Finance and Macroeconomy: Turkey Case (Turkish). Journal of Management and Economics Research 2013; 21: 185-206. [CrossRef]

8. Besiou M, Pedraza-Martinez A, Van WLN. The Effect of Earmarked Funding on Fleet Management for Relief and Development. SSRN ELECTRONICJOURNAL 2012; DOI:10.2139/ssrn.1991068; [cited 2015 December 10]. Available from: www.researchgate.net/publication/228265489_The_Effect_of_Earmarked_Funding_on_Fleet_Management_for_Relief_and_ Development.

9. Kadıoglu M, Ozdamar E. Principles of Disaster Loss Mitigation (Turkish) 1th ed. (Ankara: JICA Turkey Office, 2008).

10. Kadıoglu M. Disaster Management: Expect Unexpected, Managing the Worst (Turkish) 1th ed. (Istanbul: Turkey Republic of the Union of Municipalities of Marmara, 2011).

11. Wei YM, Fan Y, Lu C, Tsai HT. The Assessment of Vulnerability to Natural Disasters in China by Using the DEA Method. Environmental Impact Assessment Review 2004; 24: 427-39. [CrossRef]

12. Anderson MB. Vulnerability to Disaster and Sustainable Development: A General Frame Work for Assessing Vulnerability. In: Disaster Prevention for Sustainable Development (Mohan M, Caroline C, eds) (Washington, DC: World Bank, 1995: 41-51); Wisner B, Blaikie P, Cannon T, Davis L. At Risk: Natural Hazards, People's Vulnerability and Disasters. 2th ed. (New York: NY: Routledge, 2003).

13. Timmerman P. Vulnerability, Resilience and the Collapse of Society. Canada: Environmental Monograph No-1 Institute for Environmental Studies, 1981: 1-42.

14. Wilhelmi OV, Wilhite DA. Assessing Vulnerability to Agricultural Drough: A Nebraska Case Study. Natural Hazards 2002; 25: 37-58. [CrossRef]

15. Westen CV, Alkema D, Damen M, Kerle N, Kingma N. Multi-hazard risk assessment: Distance education course Guide book (Tokyo: United Nations University, 2011).

16. Coelli TJ. A Guide to DEAP Version 2.1: A Data Envelopment Analysis (Computer) Program. Centre for Efficiency and Productivity Analysis Department of Econometrics University of New England. CEPA Working Paper 96 (1996).

17. Turkey Disaster Information Bank Analysis Module (2014); [cited 2015 October 20]. Available from: https://tabb-analiz.afad.gov.tr/; Red Crescent Society of the Republic of Turkey (1868). Archives Administration. Etimesgut-Ankara; Red Crescent Society of the Republic of Turkey (1868); [cited 2015 September 20]. Available from: http://afetyonetimi.kizilay. org.tr/tr/raporlar.html.

18. Turkey Statistical Institute-Basic Statistics (2005); [cited 2015 November 05]. Available from: http://www.tuik.gov.tr/UstMenu.do?metod=temelist.

19. Cardona OD. A System of Indicator for Disaster Risk Management. 250th anniversary of the 1755 Lisbon earthquake (2014); [cited 2016 January 17]. Available from: www.unisdr.org/2005/HFdialogue/download/ tp3-paper-system-indicators.pdf.

20. Bollin C, Hidajat R. Community-based disaster risk index: pilot implementation in Indonesia. In: Measuring Vulnerability to Natural Hazards-Towards Disaster Resilient Societies (Birkmann J, ed). Tokyo, New York, Paris: UNU-Press, 2006: 271-89.

21. IDB (Inter-American Development Bank). Indicators for Disaster Risk and Risk Management: Programme for Latin-America and The Caribbean Barbados. Environment, Rural Development and Management Division (INE/RND). Technical Note IDB-TN-791 (2010).

22. Birkmann J. Risk and vulnerability indicators at different scales: Applicability, usefulness and policy implications. Environmental Hazards 2007; 7: 20-31. [CrossRef]

23. Ozceylan D, Coskun E. The Van Earthquake Post What Happened Light Significance of Social and Economic Vulnerability Study (Turkish). Eskisehir Osmangazi University Journal of Economics and Administrative Sciences 2012; 7: 167-86. 